\title{
Negotiating medical services in the Madras Presidency: the subordinate perspectives (1882-1935)
}

\author{
Arnab Chakraborty* \\ David F. Musto Centre for Drug Policy Studies, College of Liberal Arts, Shanghai University, Shanghai, China \\ ${ }^{\star}$ Corresponding author. Email: arnab0079@gmail.com
}

\begin{abstract}
The historiography of western medicine in colonial India has predominantly been analysed from the perspectives of the elite services - the Indian Medical Service (IMS) and their recruits. Unfortunately, perceiving colonial medical practices through the lens of the IMS has remained inadequate to provide a nuanced understanding of the role played by Indians in the semi-urban and rural areas of colonial India. This article examines the contributions of local administration and the role played by the recruits of the Subordinate Medical Service. This article uses the Madras Presidency as its case study and focusses on the medical subordinates who were pivotal in establishing a western medical tradition in the region. This will shift the urban-centric focus and examine mostly the rural parts of the presidency, in particular, the district hospitals and dispensaries located in the districts, taluks and villages. The article analyses the transformation in the Madras medical administration from the late nineteenth century until 1935 to argue how subordinates were the ones controlling the local medical services, and thus pulling the strings of health administration in the presidency. This will also demonstrate the uniqueness of Madras and how it disseminated western medical care with an active participation and involvement of the local residents.
\end{abstract}

Keywords: Colonial India; Madras Presidency; Medical subordinates; Health administration; Politics of health

Amna Khalid remains one of the most prominent scholars to focus on the subordinate perspectives in the context of colonial India. Although her works analyse the role of subordinates to a great extent, she does not differentiate between distinctive provincial regions, and in a highly heterogenous region like British India, it is imperative to analyse and study the provinces individually to understand and explore their complexities. ${ }^{1}$ Thus, it leaves space to concentrate on the regional differences, examining how the subordinates negotiated 'western' healthcare in rural and semi-urban spaces. ${ }^{2}$ This article will confine its focus only on one of the three officially designated presidencies of colonial India - the Madras Presidency. ${ }^{3}$ This will emphasise on the unique and distinct nature of this particular presidency in colonial India, and in this process point out the necessity of studying colonial contexts individually rather than making generalised assumptions across the empire or even across colonial India.

\footnotetext{
${ }^{1}$ See Sanjoy Bhattacharya, Mark Harrison and Michael Worboys, Fractured States: Smallpox, Public Health and Vaccination Policy in British India, 1800-1947 (New Delhi: Orient Longman, 2005) to know more about the importance of regional studies over India-wide ones.

${ }^{2}$ This article uses the word 'western' with caution, and thus the first reference has been used within quotes, but for ease of reading, and flow of arguments, western (without quotes, or capitalisation) will be used in the rest of this piece.

${ }^{3}$ The Madras Presidency was established in 1640, Bombay Presidency in 1687 and Bengal Presidency in 1690 by the English EIC who started as traders and eventually began to rule India. The territorial limits of these presidencies, however, kept changing with new acquisitions by the EIC. For a British centric report on the presidencies see, John Capper, The Three Presidencies of India: A History of the Rise and Progress of the British Indian Possessions (London: Ingram, Cooke and Co., 1853).

(C) The Author(s), 2021. Published by Cambridge University Press.
} 
From local political leaders and interpreters to medical auxiliaries, nurses, matrons, hospital orderlies, pupil midwives, asylum attendants and sweepers, the cooperation of intermediate and subordinate personnel was key to the functioning of most colonies' public health machinery. ${ }^{4}$

Madras Presidency had remained one of the most peaceful provinces during the colonial period, both under the English East India Company (EIC) and the British Crown. ${ }^{5}$ Historians have studied this presidency in terms of disease, famine, army and the police, but have largely ignored the medical services barring a few exceptions. ${ }^{6}$ This article establishes the heterogeneous nature of the presidency and the roles played by the Indian medical practitioners in the district and sub-divisional level. This work explicitly focusses on how the state policies in the presidency were altered, either willingly or under pressure, over a period of 53 years (1882-1935) - the period under review here. This article explains the role of Sub-Medical Department (SMD) and its role in preparing the ground for establishment of the European medical market in colonial Madras. ${ }^{7}$ While doing so, it will be argued that rather than a topdown approach, colonial Madras was witnessing, what is usually described in academic parlance, a bottom-up approach in terms of implementing medical policies. This article will shift the academic gaze from elites (the European officers, Surgeon General, hospital in charges, Indian elites who were a part of the IMS cadre) and focus more on the sub-assistant surgeons, local and regional dispensaries, hospital orderlies, compounders and dressers who were, as will be argued, the actual pillars of the colonial medical system in the Madras Presidency. This article will deploy James C. Scott's model of thin and thick hegemony to describe how the concept of hegemony was complex in the context of Madras Presidency. Scott's theory examines the nuances of hegemony, and in the colonial Madras, as this article will establish, understanding the flow of power between the Indian and British medical officials forms the crux of its argument. It will focus only on the western medical traditions implemented bureaucratically in the presidency and the actors who were working to implement and spread this medical tradition in the colonial state.

Through an exhaustive use of colonial official documents, unofficial publications, local newspapers and journals, this article aims to explore three major ideas. First, it maps the introduction of the submedical department in the context of colonial Madras. Second, it outlines the interaction between the British and indigenous population in the presidency both in terms of collaboration and contestation. Finally, it shows how the subordinates and those considered minors in the medical services shaped health

\footnotetext{
${ }^{4}$ Amna Khalid and Ryan Johnson, Public Health in the British Empire: Intermediaries, Subordinates and the Practice of Public Health, 1850-1960 (New York; London: Routledge, 2012), 1-31; Amna Khalid, 'Subordinate' negotiations: Indigenous staff, the colonial state and public health', in Biswamoy Pati and Mark Harrison (eds.), The Social History of Health and Medicine in Colonial India (London; New York: Routledge, 2009), 45-73.

${ }^{5}$ EIC also known as the Honourable East India Company or the British East India Company and informally as John Company, was an English and later British joint-stock company. It was formed to trade in the Indian Ocean region, initially with Mughal India and the East Indies and later with Qing China. The company ended up seizing control over large parts of the Indian subcontinent, and colonized parts of South and Southeast Asia. For more details on the EIC's formation and history, see Philip Lawson, The East India Company: A History (London: Routledge, 1993).

${ }^{6}$ Leela Sami, 'Famine, Disease, Medicine and the State in Madras Presidency (1876-78)' (PhD dissertation: University College London, 2006); David Arnold, Colonizing the Body: State Medicine and Epidemic Disease in Nineteenth-Century India (Berkeley: University of California Press, 1993); Imperial medicine and indigenous societies (Manchester: U.P., 1988); Manas Dutta, 'A study of the social composition and organization of the Madras Army 1807-85' (PhD dissertation: University of Calcutta, 2014), Introduction; Jane Buckingham, Leprosy in Colonial South India: Medicine and Confinement (Basingstoke: Palgrave, 2002); Radhika Ramasubban, 'Imperial Health in British India, 1857-1900', in Roy Macleod (ed.), Medicine and Empire: Perspectives on Western medicine and Experience of European Expansion (London; New York: Routledge, 1988); Niels Brimnes, Languished Hopes: Tuberculosis, the State and International Assistance in Twentieth-Century India (New Delhi: Orient BlackSwan, 2016).

${ }^{7}$ Sub-Medical Department was another name for the Subordinate Medical department. They had different names attached to them were also termed as apothecaries in the early days of their existence. In the later part, the article will explain the introduction and expansion of this particular department in detail. Ramya Raman and Anantha Narayanan Raman, 'Early decades of Madras Medical College: Apothecaries', The National Medical Journal of India, 29, 2 (2016), 98-102.
} 
policies in colonial Madras and brought forth the expansion of western medicine. This article will focus primarily on the Madras Presidency and how the medical subordinates reached at a position of power through negotiation and collaboration while they were employed in government-run hospitals and dispensaries, and in the twentieth century also through private practices. There will be a few comparative examples from other presidencies, but there is no similar study on other presidencies to make a comparative discussion with Madras.

\section{Subordinate medical service in the Madras Presidency: a brief historical background}

Historians have tried to examine and focus primarily on the IMS and the Royal Army Medical Corps, the latter mainly in the context of the Army. ${ }^{5}$ Following Mark Harrison's suggestion that it is essential to examine the context of medical services in colonial India by understanding their 'aspirations, priorities and grievances', this article will offer a more detailed and comprehensive study in the context of Madras. ${ }^{8}$ The Subordinate Medical Service (SMS) of Madras was established in 1812, and it was one of the earliest such departments in colonial India. ${ }^{9}$ Initially, only the non-commissioned European medical personnel were employed in this department. The Native Medical Institution was set up in 1822 by the British authorities to train people for inclusion into the SMS, but it lasted only until 1835 when there was a massive change across British India particularly in medical and healthcare policies. ${ }^{10}$ That year saw the establishment of the medical colleges in the three presidencies, and its lectures began to be delivered in English, and gradually, this started making a big impact. ${ }^{11}$ This was also the period when the EIC and the Governor-General(s) began to criticise the traditional form of healthcare and started imparting western medical education to the local residents. ${ }^{12}$ Roger Jeffery had pointed out that this was not very helpful to the locals as most of the texts were in English even though the EIC was taking some steps to incorporate them in the medical services. According to a resolution from the military department, the SMD was considered a part of the Indian Medical Service, with the recruits coming from both military and civil sections. ${ }^{13}$ The general administrative control was a liability of the Surgeon General with the government of Madras while all the members of the SMD serving with the military were under the Surgeon General of the British Indian forces. Madras Presidency had displayed an inclusive attitude towards the subordinate medical practitioners, and they even had a specific designation of 'dresser' in addition to the 'apothecaries ${ }^{14}$ who were a part of the SMS. ${ }^{15}$ As a result, from the very beginning, the Madras Presidency had been accommodating towards the SMS.

In Madras, it was mandatory for the subordinate medical personnel of the ranks of assistant apothecary and assistant dresser to take an examination (whether written or oral, is not entirely clear)

\footnotetext{
${ }^{8}$ Mark Harrison, Public health in British India: Anglo-Indian preventive medicine, 1859-1914 (Cambridge; New York: Cambridge University Press, 1994), 6-7.

${ }^{9}$ Raman and Raman, op. cit. (note 7).

${ }^{10}$ Mark Harrison, 'Medicine and orientalism: perspectives on Europe's encounter with Indian Medical Systems in Health', in B. Pati and M. Harrison (eds.), Medicine and Empire: Perspectives on Colonial India (New Delhi: Orient Longman Limited, 2001), 37-87; P. Bala, Medicine and Medical Policies in India: Social and Historical Perspectives (Lanham: Lexington Books, 2007), 68-105.

${ }^{11}$ Raman and Raman, op. cit. (note 7), 99-100.

${ }^{12}$ Roger Jeffery, 'Recognizing India's doctors: the institutionalization of medical dependency, 1918-39', Modern Asian Studies, 13, 2 (1979), 301-26.

${ }^{13}$ L/MIL/7/161-176, Military Department, Administration of the Subordinate Medical Department, Asian, African and Pacific Collections (APAC hereafter), British Library (BL hereafter); Indian Medical Service was the most prominent centralised medical service in British India, they were initially employed only for the military but later worked in civilian hospitals as well. To know more about the IMS see, Mark Harrison, Public Health in British India: Anglo-Indian Preventive Medicine, 1859-1914 (Cambridge; New York: Cambridge University Press, 1994), 6-36.

${ }^{14}$ The apothecaries were the pharmacists or chemists. But, in the context of colonial India, they were mostly the medical subordinates engaged in practicing healthcare. Raman and Raman, op. cit. (note 7), 98-102.

${ }^{15}$ Raman and Raman, op. cit. (note 7), 99-101.
} 
before promotions, and it later influenced the Bengal Presidency to adopt this as well in the $1860 \mathrm{~s} .{ }^{16}$ The Bengal medical board declared:

We concur in opinion...that it is desirable to introduce in Bengal the regulation which obtains at Madras, for subjecting subordinate medical officers to a searching examination, previous to promotion in the Department. ${ }^{17}$

The access and control of sub-medical personnel in the Madras Presidency were somewhat limited until 1880. They could only practise in the rural and semi-urban areas and in smaller medical institutions where they became indispensable as subordinates and hospital assistants taking care of district and taluk medical institutions (that is dispensaries). This proved an important aspect which contributed to them playing a significant role further up the ladder in the latter part of the history of this presidency. Until the 1880s, the SMS did not get as much importance in the medical department as they would have liked, but the political and medical scenarios began to alter during the time of Lord Ripon and with his introduction of the Resolution of $1882 .{ }^{18}$ This period saw a surge of subordinates who were willing to take necessary actions to become indispensable in terms of medical support and functioning in the hospitals and dispensaries. The following section will discuss in detail the nuances of rural and urban healthcare and the contribution of the SMS in the Madras Presidency. ${ }^{19}$ The objective here is to explain how small regional towns projected them as a viable medical marketplace attracting medical innovations and practitioners to different parts of the presidency. The control and hierarchy of the SMS will be analysed to understand the role played by the local government in establishing their control over this medical marketplace. ${ }^{20}$ Thus, it will be argued that in the latter half of the period under review, these smaller, local spaces could control and influence major decisions concerning the presidency at the provincial level.

\section{Local self-government resolution and a shift in the subordinate medical service}

This section examines how the medical subordinates were treated and how their situation began to alter following the local self-government resolution. This period also witnessed a gradual shift of medical personnel from predominantly military focussed medical service to a more overarching and lucrative civilian medical services. While analysing the period, the equation between different strata of local population will be examined as well, to emphasise on how negotiation among Indians positioned in different administrative responsibilities plays a significant role. The medical services in Madras underwent significant changes with the Resolution of 1882 during the Viceroyalty of Lord Ripon. Ripon made it quite evident that he wanted to give the locals better opportunities to work with the government and thus focussed more on decentralising the administration. It is, however, important to note that the idea of

\footnotetext{
${ }^{16} \mathrm{Q} / 2 / 8 / 8$, Memorandum on the Civil Apothecaries in the Madras Presidency, APAC, BL.

${ }^{17}$ Raman and Raman, op. cit. (note 7), 101.

${ }^{18}$ Local self-Government was introduced in India by the Resolution of 1882 during the Viceroyalty of Lord Ripon. This led to higher participation of Indians in local administrative matters and led to establishment of District and Local boards. The members of the boards were also to be partly nominated and partly elected. This led to the rise of local influence in local, regional politics of India which changed the political dynamics of India. See H. Wheeler, 'Local Self-Government in India', Journal of the Society of Comparative Legislation, 17, 1/2 (1917), 153-64.

${ }^{19}$ This article uses healthcare as an umbrella term, to explain the nuances in public health during the period, since, this article deals with western from of medical practices that were imposed on the colonised population with the introduction of medical care for the military.

${ }^{20}$ In 1985, Roy Porter wrote of the premodern 'medical marketplace' 'where physicians, surgeons and apothecaries ... melted into each other along a spectrum that included thousands who dispensed medicine full or part time'; For more details see, Mark Jenner and P. Wallis, 'The Medical Marketplace', in Mark Jenner and P. Wallis (eds.), Medicine and the Market in England and its Colonies, c.1450-850 (London: Palgrave Macmillan, 2007).
} 
local self-government was prevalent much before the late nineteenth century in this region. ${ }^{21}$ Like the elite medical service, the SMS was also initially established to look after the British Indian army, but it changed its structure and composition drastically over the years and in the late nineteenth century, with the increased local influence they were looking for opportunities to control the civilian medical administration. There were people voicing support for the subordinates from as early as 1882 , which is evident from a letter to the editor of the $I M G$ arguing that these medics 'secretly pine away in their degraded condition'. ${ }^{22}$ The letter expressed concern about the unqualified practitioners and this brought to the fore the brewing conflict among different layers of Indians over their access to the medical marketplace. $^{23}$

In 1882, there were eleven hospitals in the districts of Madras, usually located at the taluk headquarters. ${ }^{24}$ In-patients were not encouraged to visit the dispensaries by the medics as much as out-patients as there were no medical schools attached to such medical institutions. The financial condition of individual residents impacted their decision to get admitted as in-patients. Only the poorer section showed any willingness for this, particularly in high-risk cases such as epidemics. ${ }^{25}$ Indeed, it is impossible to understand the subordinate or lower division of the medical services without addressing the conflict of interest among different layers of the local population. The colonised people were not a homogenous entity, and there were divisions based on caste, religion, language, race and ethnicity among the subject population inside the presidency of Madras. D.G. Crawford's book pointed out that certain roles were approved for the uncovenanted medical officers, opened to Indians in the Bengal Presidency, which applied to all the presidencies. ${ }^{26}$ Out of several rules, the one that allowed the provincial government to control the transfers of medical practitioners inside the provinces at their discretion strictly defined the role of provincial and central governments. The Government of India (GoI) had their final say in matters of transfer to a different presidency, but it was not the case inside Madras Presidency. The GoI found it difficult to control the provincial matters, and this permitted the provinces to act independently of the central command sitting in Calcutta. ${ }^{27}$ Until 1881, the GoI had always maintained their intention and inclination towards the covenanted ${ }^{28}$ services and the uncovenanted ones had no way to reach covenanted positions. ${ }^{29}$ However, the Secretary to the government of Madras enquired, during the period, if they could employ an apothecary named John Norman in a civil medical charge, which alludes to the elevating prestige and fortune of the apothecaries in Madras by $1884 .{ }^{30}$ In the same period, the lower strata of the healthcare system in Madras was subtly altered, and while the name 'apothecaries' remained for the medical apprentices, the system of 'stipended pupilage' was discontinued, and the civil apothecary grade was abolished. ${ }^{31}$

To understand the conflict of ideas at the local level, one needs to first investigate the equation between the western and local medical forms that had an impact on the local populace. The most common way of undermining the 'indigenous' form of medicine, by the colonial government, was by

\footnotetext{
${ }^{21}$ K.K. Pillay, History of Local Self-Government in the Madras Presidency, 1850-1919 (Bombay: C.D. Barfivala, Director, The Local Self- Government Institute, 1953), 1-5.

${ }^{22}$ 'Pay of the Subordinate Medical Department', Indian Medical Gazette, 17, 10 (1882), 279-80.

${ }^{23}$ Ibid.

${ }^{24}$ Dewan Bahadur S. Srinivasa Raghavaiyangar, Memorandum on the progress of the Madras Presidency, 1892; Taluk used to be a sub-division of a district, in charge of a number of villages.

${ }^{25}$ Ibid.

${ }^{26}$ D.G. Crawford, A History of the Indian Medical Service, 1600-1913 (London: W. Thacker, 1914), 110-25.

${ }^{27}$ Ibid.

${ }^{28}$ The covenanted positions were open to only Europeans while the uncovenanted positions were opened to allow Indians to join the Government services. Thus, there was a clear segregation between the two types of positions. Later, with higher representation of Indians, the uncovenanted position holders were promoted to become covenanted in few cases. For more details on this, The Medical Reporter: A Record of Medicine, Surgery, Public Health and of General Medical Intelligence (Calcutta: 'Medical Publishing' Press, 1892-95), 219-21.

${ }^{29}$ Home (Medical), G.O. No. 428, 11 October 1884, APAC, BL.

${ }^{30} \mathrm{Ibid}$.

${ }^{31} \mathrm{Q} / 2 / 8 / 8$, op. cit. (note 16 ).
} 
highlighting the differences between the two forms of medicine. Indigenous medicine was criticized for being 'unscientific' and attention was drawn to its apparent lack of 'hands-on approach' to portray it as 'inferior' to western medicine. Poonam Bala and Mark Harrison have pointed out how with the aid of scholarships, free medical texts, government backing and well-equipped institutions, the western trained medical practitioners began to provide strong competition to the indigenous medics. ${ }^{32}$ In colonial medical policies, the resistance of subordinates and colonised people have not been given adequate space in the existing literature. This has diminished the subordinates' position, and the existing historiography has underplayed the power they wielded in the lower rungs of the administration.

The SMD in colonial India was divided into two branches, one for the military and other for the civil population. ${ }^{33}$ But it had finer divisions as well: the senior branch consisted of apothecaries and assistant apothecaries, nearly all Anglo-Indians, who were usually employed on civil duty or attached to large station hospitals, and the junior branch consisted of three grades of hospital assistants, mostly local Indians. ${ }^{34}$ This branch deployed men mostly attached to native regiments, and they usually ranked below native commissioned, but above non-commissioned officers. ${ }^{35}$ In Madras, men were enlisted as medical pupils between ages of 15 and 19, after qualifying by exam they had to be attached for 2 years to a civil or military hospital and only after that they were deemed qualified enough for the grade of hospital assistant and were employed in the junior department of Madras Medical College. ${ }^{36}$ In 1885, a circular issued from Fort William (Calcutta) instructed that the members of the hospital assistant group could only be employed in hospitals of 'native' troops and followers, in lock-hospitals and in staff appointments. ${ }^{37}$ The senior hospital assistants had to oversee the whole group with first and second-grade hospital assistants and sub-hospital assistant working as subordinates. This whole group of people were ranked below all the 'native commissioned' officers and medical warrant officers but were above the ranks of all 'native noncommissioned' ones. ${ }^{38}$ These different layers in the subordinate services were distinct in terms of their responsibilities. Their roles were supposed to be mostly for the military, but they were also allowed to work in the lock-hospitals and in the Indian marine division, and an extra 15\% were kept aside for temporary duties and to work as substitutes of absentees or sick people. ${ }^{39}$

In the late 1880s, a new degree of Licentiate Medical Practitioners (LMP) was introduced which replaced the certificate of civil apothecaries, and the provincial government assured local residents that no special importance was attached to the new degree. ${ }^{40}$ The government realised that the pay offered in these positions was far too little to attract people for long. All these factors compelled the Madras government to increase the pay of the subordinates. ${ }^{41}$ However, in those initial years, the segregation was intensive, and apothecaries were prevented from ever reaching the level of the civil assistant surgeons and civil hospital assistants. Moreover, in terms of pay, the system was tilted against apothecaries in such a way that only after 28 years of full service were, they able to reach their maximum pay grade. ${ }^{42}$ They were not allowed to draw their full pension if they retired before 31 years of service. The government persisted in treating them only as a temporary solution rather than as having a permanent role in the service until the twentieth century. ${ }^{43}$

\footnotetext{
${ }^{32}$ Poonam Bala, Medicine and Medical Policies in India: Social and Historical Perspectives (Lanham; Plymouth: Lexington Books, 2007); Mark Harrison, Public health in British India: Anglo-Indian Preventive Medicine, 1859-1914 (Cambridge; New York: Cambridge University Press, 1994).

${ }^{33} \mathrm{IOR} / \mathrm{P} / 1664$, no. 12-13, Memorandum of the Army Sanitary Commission 1881, APAC, BL.

${ }^{34}$ Ibid.

${ }^{35}$ Ibid.

${ }^{36}$ Military Department (Medical), Army Circular, 31 July 1885, National Archive of India (NAI hereafter).

${ }^{37}$ Ibid.

${ }^{38}$ Ibid.

${ }^{39} \mathrm{Ibid}$.

${ }^{40} \mathrm{Q} / 2 / 8 / 8$, Memorandum on the Civil Apothecaries in the Madras Presidency, BL.

${ }^{41}$ Ibid.

${ }^{42}$ Ibid.

${ }^{43}$ Ibid.
} 
The Surgeon-General of Madras stated in his report in 1891 that the districts under the charge of medical officers were much larger in area and contained a far greater number of dispensaries than any other parts of British India, and the District Medical Officers (DMOs) were mostly busy undertaking their administrative duties in such big districts. ${ }^{44}$ This resulted in them being absent from the headquarters for a considerable amount of time, and the subordinates taking up their mantle in conducting surgeries or treating people in their absence. ${ }^{45}$ This made Madras a unique place from the point of view of rural healthcare in British India. ${ }^{46}$ The provincial government of Madras had difficulty explaining to the central government in Calcutta, why they needed to consider the number of dispensaries and not merely the number of patients being treated by the DMOs. ${ }^{47}$ Such issues compelled the GoI to increase the number of commissioned medical officers in Madras from being fixed at 122 in 1885 to 136 in 1891 . Even this expanded force was insufficient to meet the needs of such a big presidency with so many dispensaries and district hospitals. ${ }^{48}$ The civil requirements were becoming difficult to meet, and thus the assistant surgeons were being positioned in charge of several medical institutions. ${ }^{49}$ The GoI and the military department by the 1890s had altered their stance against the civilian medical services. They believed,

... the requirements should be met by doubling up under one medical officer the medical charges of two or more Native regiments serving at the same station, instead of calling upon the Civil Department to surrender officers to meet their demand. ${ }^{50}$

The GoI, more importantly, the military department, began to comprehend the importance of the civilian medical department by mid-1890s and encouraged more Indians to join the medical force, particularly in Madras where the Army Medical Service was passing through a difficult time and military service would force the recruits to move far from their home. The medical officers were overworked, and the medical subordinates stepped up to conduct surgeries in the absence of their senior officers. Files from the military department and local newspaper reports corroborate that the local Indian subordinates began to get engaged in more numbers to perform major surgeries taking up higher ranks in district hospitals and dispensaries. ${ }^{51}$ In the process, they steadily became a part of the medical marketplace in Madras. This process persisted until the beginning of the twentieth century and benefitted the increasing number of subordinates joining medical services, and they extended the practice in the rural regions.

Although, the names of lower ranked hospital assistants who performed similar important operations usually remained undisclosed in the annual reports and official statements. The Surgeon-General of Madras stated that in accordance with instructions from the Madras government, such lists included no officers below the rank of assistant surgeons. ${ }^{52}$ Despite this deliberate omission, the government was generally considerate of local politics and was careful to not antagonise public sentiment. They were careful about any 'breach of conduct' against the subordinates as had been evident in the case of a Major Hakim, where the government dealt with his complaint of misbehaviour by a British official seriously. ${ }^{53}$

\footnotetext{
${ }^{44}$ Report of the SG on civil Hospitals and Dispensaries in the Madras Presidency for the year 1889, Indian Medical Proceedings, No. 669, 6 August 1891, APAC, BL.

${ }^{45}$ Ibid.

${ }^{46}$ For a similar engagement on dispensaries in the Bombay Presidency, see Mridula Ramanna, Western Medicine and Public Health in colonial Bombay, 1845-95 (London: Orient Longman, 2002). This article would not delve into further detail as this article will refrain from making comparative study with another presidency.

${ }^{47}$ Ibid.

${ }^{48}$ Despatch from the GoI, Military Department, no. 223, 28 October 1891, APAC, BL.

${ }^{49}$ Military Department, No. 431, 15 July 1891, APAC, BL.

${ }^{50}$ Ibid.

${ }^{51}$ 'Supply of Medicines to Local Fund Dispensaries', The Hindu January 11, 1894, 5; Military Department, No. 431, 15 July 1891, APAC, BL.

${ }^{52}$ Home Department Proceedings, G.O. No. 209, Part 1, 1899, APAC, BL. This is, however, the case with Madras Presidency, there has been records of similar names in the Bengal Presidency.

${ }^{53}$ Ibid.
} 
Table 1. Statistics of the number of dispensaries and the patients.

\begin{tabular}{cccccc}
\hline Province & $\begin{array}{c}\text { Number of } \\
\text { dispensaries }\end{array}$ & $\begin{array}{c}\text { Area of the provinces } \\
\text { in square miles }\end{array}$ & $\begin{array}{c}\text { Square miles } \\
\text { per dispensary }\end{array}$ & $\begin{array}{c}\text { Population per } \\
\text { dispensary }\end{array}$ & $\begin{array}{c}\text { Number of patients } \\
\text { treated per dispensary }\end{array}$ \\
\hline Bengal & 479 & 151543 & 318 & 147527 & 5941 \\
\hline Madras & 475 & 141189 & 297 & 75011 & 8519 \\
\hline
\end{tabular}

Source: No. 1081, Public, dated 25 August 1898, Home Department Proceedings, 1899, APAC, BL.

It was difficult to find any further details on this particular issue, and therefore is hard to understand if it was a one-off incident or was usually the case in the late nineteenth century Madras presidency. The formal training of apothecaries was stopped by the later decades of the nineteenth century, although informal training continued, especially for army cadets and women in Madras Presidency. Schools in Royapuram (developed later as Stanley Medical college and hospital), Thanjavur and Madurai were created to train medical practitioners and grant them titles of LMP. ${ }^{54}$

By the end of the nineteenth century, apothecaries had unofficially evolved into general practitioners of medicine in this presidency. ${ }^{55}$ The gradual enhancement of the identity of the apothecaries meant the rise of the 'qualified' medical practitioners who distanced themselves from Indians holding lower positions. ${ }^{56}$ This exposed the hierarchical segregation among Indians working at different levels of the medical administration. The government intended to change the dynamics of the British system of medical education and 'allow' more people to join the medical department. ${ }^{57}$ With the gradual disappearance of the title of the apothecary in the Madras Presidency, the existing practitioners were re-designated as assistant surgeons and were recognised as 'qualified' medical personnel registered under the Indian Medical Act. ${ }^{58}$ Promotion from the rank of sub-hospital assistant to that of hospital assistant was made according to seniority, provided the candidate was well connected and was considered efficient. ${ }^{59}$ Towards the end of the nineteenth century, the number of dispensaries and population per dispensary in the presidency was highest in the country.

With the advent of the twentieth century, the Madras Presidency had dispensaries widely spread out across the region catering to a much larger number of local people in total, as illustrated by the table above. ${ }^{60}$ Table 1 shows how Madras had provided access to western medicine in its rural areas, including the district hospitals, taluks and dispensaries. The number of dispensaries increased consistently every year, and so did the number of patients coming to the dispensaries. Madras recorded the highest number of patients being treated in the rural sectors starting from $1896 .{ }^{61}$ The number of operations conducted in the presidencies also evinced that hospitals and dispensaries in Madras conducted many more operations than any other provinces in 1896 and $1897 .{ }^{62}$ These were the initial days when Madras was slowly changing and evolving its medical policies to extend services to more people, particularly in the rural areas. The urban areas were also reaping the benefits of the western medical surge in Madras, and they began to reach out to the districts after the Madras city began to get overcrowded by medical

\footnotetext{
${ }^{54}$ Raman and Raman, op. cit. (note 6), 5.

${ }^{55}$ Report of the Committee Appointed by the Government of India to Examine the Question of the Reorganisation of the Medical Services in India (Shimla: Government Central Press, 1919), 9.

${ }^{56}$ The term 'qualified' must also be understood in a nuanced way. The Madras government only considered those people as qualified who were willing to contribute to the expansion of western medicine. This led to a competition between Indians to get better opportunities and positions as will be explained later.

${ }^{57}$ The colonial government in Madras by this time was willing to accept more Indians into their ranks and this was evident from the change of their policy; IOR/L/MIL/7/5293, Apothecary Branch: Changes in rank and designation of Members, Military Department, 1893-94, APAC, BL.

${ }^{58}$ IOR/L/MIL/7/5293, Apothecary Branch: Changes in rank and designation of Members, APAC, BL.

${ }^{59}$ Ibid; 'Araciyalum cukātāramum' (Politics and Health) (V.S. Venkataraman Kempeni, 1900).

${ }^{60}$ Home Department Proceedings, G.O. No. 1081, Public, 25 August 1898, BL.

${ }^{61}$ Ibid.

${ }^{62}$ Ibid.
} 
practitioners. The civil medical department began to feel the pressure as the IMS officers were constantly called for military duties. It also made the Madras government realise the importance of a change in attitude and separation of the military and medical sectors to allocate more space for civil medical practitioners in the medical services. ${ }^{63}$ Such factors contributed to the changing attitude of the provincial government and alongside the local inhabitants were gradually showing more interest in healthcare, at least in the urban areas.

The alarmingly low number of IMS officers in the districts and other sub-divisional hospital charges compelled the government of Madras to look for assistant surgeons and warrant medical officers who were to be placed in the medical charge of civil stations in the absence of the civil surgeons. This became even more essential as the civil surgeons had to devote time to their administrative and other additional responsibilities and rarely had the opportunity to pay attention to the daily activities and healthcare set up of the hospitals. ${ }^{64}$ The same period also witnessed the beginning of a consistent shift in the outlook of medical treatment from military to a more civil centric approach to healthcare. The GoI had agreed to allow the permanent transfer of the warrant medical officers from military to the civilian department in order to reduce the number of supernumeraries and to relieve the stagnation in ranks, particularly outside the presidency town. ${ }^{65}$ While the Madras government was looking for an overall transfer from military to civil services, a careful analysis of the reports showed that conflict was brewing among the Madras officials and the GoI. ${ }^{66}$ Although the GoI was repeatedly displaying its intention to retain more medical officers for the army, the Surgeon-General of Madras and the Secretary were, in turn, piling up pressure on the GoI to station more physicians in the civilian hospitals. ${ }^{67}$ Within 1 year, several requests and letters were sent to the GoI requesting resources in the form of both men and money. This highlights that the central and provincial governments were rarely on the same page when it came to provide medical care in the Madras Presidency.

By 1903, proposals were forwarded to restructure the SMS in Madras. In a letter written to the Secretary of State for India, it was declared that the post of apothecaries for the Madras Presidency would be done away with. ${ }^{68}$ It was proposed by the Surgeon-General in Madras to assimilate the existing apothecaries with civil assistant surgeons, which would translate to these apothecaries working as assistant surgeons. ${ }^{69}$ There was also discontent between the provincial government in Madras and the central government in India regarding the maintenance of the reserve medical force in the presidency. Certain local organisations were working to focus on the villages, and taluk health issues, and how they were controlled by the indigenous people at ground levels. ${ }^{70}$ The central committee decided in favour of the provincial government, thus enunciating that provincial administration was allowed more autonomy than before to act on their own accord in the majority of occasions. ${ }^{71}$

The apothecaries, while in public hospital service, held the rank of warrant officers and were permitted to practise medicine privately. Under these circumstances, the evolution of apothecaries (and dressers) in Madras Presidency was recognised more as a medical force, than a paramedical one (although apothecaries used the title of 'Mister' rather than 'Doctor'). ${ }^{72}$ There were very stringent rules in place to bind the people to the service. One such rule made it obligatory for the sub-hospital assistants to

\footnotetext{
${ }^{63}$ Ibid.

${ }^{64}$ Home Department (Public), G.O. No. 493, Ootacamund, 8 July 1890, APAC, BL.

${ }^{65}$ Home Department, G.O. No. 4931D, Fort William, 31 December 1890, APAC, BL.

${ }^{66} \mathrm{Ibid}$.

${ }^{67}$ Home Department, G.O. No. 37, 19 January 1891, APAC, BL.

${ }^{68}$ Finance and Commerce Department, Medical, No. 253 of 1903, NAI.

${ }^{69}$ Ibid. Explained.

${ }^{70}$ 'Kirāma cukātāra vilakkam' (Village Health Description), Christian Literature Society for India, 1897; 'Kirāma municīp mānyyūl' (Village Municipal Manual), Madukaraveni Book Depot, 1900; 'Civil Hospitals and Dispensaries in Madras', The Hindu September 3, 1906, 1.

${ }^{71 ،}$ 'Civil Hospitals and Dispensaries in Madras', The Hindu September 3, 1906, 1.

${ }^{72}$ The reorganisation of the SMD in the Madras Presidency. (Extract from the proceedings of the GoI, Finance and No. 87 Commerce Dept., No 7393, 5 December 1903.)
} 
sign a declaration to serve the government for a period of 7 years in the rank of hospital assistant unless prevented by physical disability. In case, they applied for discharge before 7 years, they had to refund the amount of salary received during their entire period of service. After completing 7 years, they could theoretically claim their discharge, but this was allowed only during peacetime. ${ }^{73}$

In the initial years of the twentieth century, the SMD went through a process of reorganisation which, as evident from the records, further strengthened the service and the manner in which it operated in the districts of Madras Presidency. The Secretary of State for India sent a letter approving a scheme that led to the amalgamation of the three existing classes of civil assistant surgeons, temporary assistant surgeons and civil apothecaries, into a single class of civil assistant surgeons, with payments commencing from Rs. 100 and rising up to Rs. $150-200$ per month. ${ }^{74}$ It was also simultaneously proposed that more permanent positions would be opened and the temporary ones were to be replaced by civil assistant surgeons. ${ }^{75}$ Thus the subordinates were scaling a new rung in the hierarchy in the early years of the twentieth century.

The Madras government was looking for new recruits in the medical department among Indians, which directly led the number of subordinate officers to swell. ${ }^{76}$ Most of the subordinate medical appointments in Madras were held by civil apothecaries by early 1900s. ${ }^{77}$ With the creation of the new designations discussed earlier in this article, the civil assistant surgeons became an essential part of the colonial medical set up. Hospital assistants and equivalent grades were eligible for transfer to the military department and were graded, in the first place, according to their standing at that time. ${ }^{78}$ All future appointments, it was decided, were to be made from qualified medical pupils, and all were dutybound to serve the military, even if primarily employed in the civil department. ${ }^{79}$ The senior hospital assistants were granted commissions - the first class ranked as subadars, ${ }^{80}$ the second class as jemadars. ${ }^{81}$ All hospital assistants were granted warrant rank but were always junior in rank to all military assistant surgeons. The finance department, however, proposed in the first decade of 1900, the abolition of the method of dual control of the European and 'native' subordinates. As there was collusion between the two groups, Madras government feared that the joint responsibility of Europeans and Indians gave rise to illicit methods of making money and decided to take action to stop any malpractice. ${ }^{82}$ This was aimed to maintain control over the medical practice as Indians were steadily becoming their competitors, which was not particularly appreciated by the colonial government.

In April 1910, the designation of hospital assistant was changed to the sub-assistant surgeon. ${ }^{83}$ With effect from May 1912, the GoI sanctioned the following enhanced rates of pay for military sub-assistant surgeons, as they realised the importance of giving them a hike in order to attract more young Indian graduates. ${ }^{84}$

As Table 2 shows, this enhanced pay for the subordinate service is proof of their rising importance and that of government interest that they had begun to garner. The contribution and control of the local bodies in matters of administration and healthcare were significant even before the Great War. The

\footnotetext{
${ }^{73}$ Finance and Commerce Department, Medical, No. 253 of 1903, NAI.

${ }^{74}$ The reorganisation of the SMD (Extract dated 5 December 1903), NAI.

${ }^{75}$ Ibid.

${ }^{76}$ Army Department, April 1920, 2413-17, NAI.

${ }^{77}$ Ibid.

${ }^{78}$ Ibid.

${ }^{79}$ Crawford, op. cit. (note 26), 120.

${ }^{80}$ Subadar was a rank in the British Indian Army. They had an equivalent rank of a British Captain and were placed below British Commissioned officers and above non-commissioned ones. For more details on the British Indian army ranks See, Tarak Barkawi, Soldiers of Empire: Indian and British Armies in World War II (Cambridge: Cambridge University Press, 2017).

${ }^{81}$ Jemadar was the lowest rank for Viceroy's commissioned officers in colonial India. For more details on the British Indian army ranks, see Barkawi, Soldiers of Empire.

${ }^{82}$ Military Department, September 1902, Nos. 1576-7. NAI.

${ }^{83}$ Committee Report, 6.

${ }^{84}$ Ibid., 7-9.
} 
Table 2. Salary structure of the medical subordinates.

\begin{tabular}{lc}
\hline (A) Senior sub-assistant surgeons & Salary \\
\hline (i) First class, ranking as Subadar & Rs. 110 \\
\hline (ii) Second class, ranking as Jemadar & Rs. 90 \\
\hline (B) Indian warrant officers & \\
\hline (i) Sub-assistant surgeons, first class & Rs. 70 \\
\hline (ii) Sub-assistant surgeons, second class & Rs. 50 \\
\hline (iii) Sub-assistant surgeons, third class & Rs. 35 \\
\hline
\end{tabular}

Source: Committee Report, 1919.

official correspondences showed caution about the huge influx of subordinates. ${ }^{85}$ The war efforts depleted the civil side of the Indian Medical Service, and these vacant positions were taken up by the medical subordinates, compounders and people with very limited medical knowledge both in the rural and urban areas. The following section will further elaborate on how the SMS began to expand their dominance in the presidency.

\section{World War I and dominance of the subordinate medical service in Madras health services}

The Great War triggered a change in the medical hierarchy of the Madras Presidency, and the subsequent shifts during the war time made a significant contribution to the way medical services operated in the region. The locals in the districts of Madras Presidency were fast gaining a foothold and obscuring the divisions in the hierarchical structure, much to the discomfort of the IMS officers. In 1913, the medical and sanitary officer of Salem (a district in Madras) voiced his concern regarding the power wielded by the lower level people in the rural areas. ${ }^{86}$ Lieutenant Colonel R.K. Mitter of Salem was not subtle in expressing his discontent about the taluks and district boards and the people who were controlling these, including tahsildars, and sub-inspectors, who were basically subordinates. He went on to say that the 'actual control of medical institutions is vested in the hands of these, and they have the power to reject the District Surgeon's recommendations and upset his arrangements' ${ }^{87}$ This complaint coming from a senior officer strongly indicated the looming discontent among the high ranking officers over the rising power and authority of medical subordinates in the presidency. Apart from the pay, the responsibilities also differed for different designations. The medical charges of small districts and important subdivisional hospitals as well as lectureships of the medical schools and access of the medical colleges were opened to the civil assistant surgeons and civil apothecaries of the first and second grades by selection. ${ }^{88}$

The War caused a huge dent in the healthcare setup in colonial Madras and it forced the government of Madras to look for more teachers and trainers, as the number of medical students and patients were both increasing. This move by the provincial government presented an opportunity for Indians to join the medical service in large numbers and get trained in western healthcare. There was the added advantage of knowing one of the 'native languages' and the diseases peculiar to the region. ${ }^{89}$ As the importance of local people increased in the SMS, the IMS also started accepting more Indians in its rank.

The First World War depleted the civil side of the Indian Medical Service, and the government of Madras realised that medical provisions for the presidency were inadequate. Sir Harold Stuart claimed

\footnotetext{
${ }^{85}$ Crawford, op. cit. (note 26), vol. II, 119-22.

${ }^{86} \mathrm{Q} / 2 / 1 / 238$, The Representation of Lieutenant Colonel R.K. Mitter, APAC, BL.

${ }^{87} \mathrm{Ibid}$.

${ }^{88} \mathrm{Q} / 2 / 1 / 236$, Memorandum by Civil Apothecary, A.S. Vittal Rau, February 1913, APAC, BL.

${ }^{89} \mathrm{~S}$. Ramasubbu, 'Rural medical relief, The Medical Practitioner 1 (1929), 20-4.
} 
Table 3. Number of subordinates in three districts of Madras from 1915-18.

\begin{tabular}{lcccr}
\hline Medical School & 1915 & 1916 & 1917 & 1918 \\
\hline Royapuram & 49 & 120 & 117 & 129 \\
\hline Tanjore & 122 & 123 & 132 & 148 \\
\hline Vizagapatam & 98 & 96 & 112 & 147 \\
\hline
\end{tabular}

Source: Local and Municipal (Medical), No. 54, 8 February 1918, APAC, BL.

during a lecture in the MMC in 1916 that the medical provisions present in Madras were 'ridiculously inadequate'.$^{90}$ By the end of 1915 , in the midst of the Great War, only one hospital or dispensary catered to every 600 square miles in the presidency. ${ }^{91}$ Many villages were far off from any health centres, and there were almost no private practitioners in rural areas. ${ }^{92}$ During this period, funds were hard to come by, and it became difficult to receive any provision from the GoI or the provincial government in Madras. The district and municipal boards were unable to take on the entire responsibility of building new dispensaries or hospitals along with the necessary pieces of equipment. ${ }^{93}$ This paved the way for a new method of spreading healthcare across rural areas through travelling medics. The sub-assistant surgeons were asked to go on frequent tours equipped with medicine chests and given permission to attend to all urgent cases or minor ailments. Only the more serious cases or those requiring operations were referred to the circle hospitals. ${ }^{94}$

Finding money for infrastructure was equally challenging, given the war time situation. The Madras government with the Surgeon-General G.G. Giffard came up with a plan to involve more private donors to establish hospitals in rural areas and districts. For the proposed hospital in Madurai in 1918, the government memorandum declared that they would name individual blocks of the hospital after the donors of the hospital. ${ }^{95}$ This approach was adopted by the GoI and was implemented in various districts as the local wealthy inhabitants were keen on engraving their names on the burgeoning health infrastructure. ${ }^{96}$ This move encouraged more wealthy local residents to donate money for the cause. The amount of control the local population, even in the districts, had on the expansion of western medicine in the Madras Presidency is quite apparent from this decision. The number of Indians opting to study medicine in medical schools was also on the rise. The superintendent of Royapuram medical school proposed to appoint senior grade sub-assistant surgeon Asirvada Nadar, and fourth-grade subassistant surgeon P.M. Sridharan attached to first District and Rajah Sir Ramaswami Mudaliar's Lying-in hospital, Madras, respectively, as assistant anatomical instructors in the Royapuram Medical School for 9 months from 1 July 1916. ${ }^{97}$ Table 3 represents the rise in the number of Indians in medical schools across the presidency and, depicts the steady increase in the numbers for most places. This resulted in more Indians being recruited and trained for imparting medical education and establishing healthcare practices across the presidency.

There were regular contestations between the appointees of the GoI and those of the local governments, that is the medical subordinates. The jail superintendents of the central jails disregarded and discouraged the medical subordinates who were serving in these jails and such actions gave rise to several

\footnotetext{
${ }^{90}$ Extract from The Hindu 15 August 1916, Madras Medical Proceedings, 1917.

${ }^{91}$ No. 68 (Medical), Local and Municipal Department, 1917, APAC, BL.

${ }^{92}$ Ibid.

${ }^{93}$ Ibid.

${ }^{94} \mathrm{Ibid}$.

${ }^{95}$ G.O. No. 54, Local and Municipal (Medical), 8 February 1918, APAC, BL.

${ }^{96}$ Ibid.

${ }^{97}$ G.O. No. 3914, Public Department, 23 June 1916, Tamil Nadu State Archive (TNSA hereafter).
} 
conflicts among factions. ${ }^{98}$ These constant complications forced the GoI to consider removing the medical subordinates working in the jails and replacing them with compounders, thus designating them as subordinate cadres. ${ }^{99}$ The compounders were then made responsible for medical scenarios inside the district and sub-jails, and the sub-assistant surgeons by this time were regarded as far too important to be spending their time engaging in conflicts with the jailors and hence began to be placed in higher positions across the presidency. The Madras government could identify the glaring problem of not having enough western medical practitioners in the districts and taluks in this period. A survey conducted in 1917-18 revealed that in Madras in most occasions only one single registered practitioner of western medicine could be found in towns with around 8000 inhabitants. ${ }^{100}$

The district boards began to take an interest in recruiting medical officers for the locally funded medical institutions instead of obtaining the services of the officers under the government. With pressure mounting on the government and with the lack of medical practitioners in their employment, the district boards were given the authority to appoint their own medical officers although they were not supposed to exceed more than $25 \%$ of the posts under them. ${ }^{101}$ The provincial government began to realise the importance of encouraging more subordinates to join and hence took the decision of abolishing the mandatory training for the civil assistant surgeons and sub-assistant surgeons. The training was a cause of dissent among the subordinate services, and they considered it their victory when this was abolished, although measures were taken so that the recruits could continue to develop their skills. ${ }^{102}$ Even though the number of medical graduates increased manifold, they continued to overcrowd the existing marketplace rather than try to expand its boundaries beyond the urban settlements. At one point, the towns, and in particular Madras city, were teeming with medical practitioners, whereas the districts and villages suffered from a dearth. ${ }^{103}$ The expanse of the Madras Presidency made it harder for the locals and the government to understand and administer the province as a single entity. With diverse languages, cultures, religions and classes co-existing in the Madras Presidency, it was problematic to even decide upon a common vernacular that would be understood by all sections of the populace. For example, the district of Ganjam had Oriya speaking people who were not used to Telugu or Tamil language speakers who were in charge of most of the rural medical institutions in the presidency. ${ }^{104}$ Thus, imagining the presidency, let alone the whole of British India, as a monolithic structure is not a nuanced approach. Such complications made it more difficult for the British administrators to effectively control the local medical administration and ensure that the medical practitioners operated at their command.

In order to have an effective system of healthcare in place, all district boards were required to employ a health officer in each district as per the government directive. There were certain reasons behind the transformation of subordinate medical structure in Madras Presidency. The provincial government declared that municipal councils that generated income of more than Rs. 100000 in the previous three consecutive years were required to appoint their own health officers. ${ }^{105}$ This particular move enabled local political leaders to exert more control as the district council or the president of the district boards was entrusted with the power of appointing health officers. ${ }^{106}$ This move was hastily put together during the Great War but failed to bring any improvement to the district health centres. In 1915, the government again formulated a scheme to appoint health officers in ten municipal towns. ${ }^{107}$ Between 1917 and 1920,

\footnotetext{
${ }^{98}$ 'Humiliation of Medical subordinates attached to jails', Indian Medical Journal (1922), 45-50.

${ }^{99}$ Ibid.

${ }^{100}$ Committee Report, 22.

${ }^{101}$ IOR Mss Eur F77/189, The working of the system of Government: Administration of Departments, 125, APAC, BL.

${ }^{102}$ Ibid.

${ }^{103}$ Op. cit. (note 100).

${ }^{104}$ IOR Mss Eur F 77/187, Redistribution of the provincial area: Madras Presidency, APAC, BL.

${ }^{105}$ IOR Mss Eur F77/189, 138-9, APAC, BL.

${ }^{106}$ Ibid.

${ }^{107}$ Ibid.
} 
the government took over the management of almost all district headquarters in order to make them efficient and more importantly, to attract more medical practitioners to the districts and rural areas. ${ }^{108}$ Following the end of the War, the government was financially weak, but even more limiting to it than the financial constraints was the severe shortage of people to work in the rural districts and taluks. ${ }^{109}$ To deal with the mounting pressure of appointing more Indians and having a separate body for treating civilians, a decision was taken to change the name of the SMD. In 1918, it was renamed as the Indian Medical Department to elevate the status of the subordinates and make them more enthusiastic about working in the rural and semi-urban spaces. ${ }^{110}$ The local politicians began to take more interest in the development of civilian medical services, and this tilted the power dynamics in favour of the subordinates. This also provided them with space and opportunity to sell their skills in the medical marketplace that was distinctly expanding in Madras. Private practice was a matter of importance to the medical practitioners, as that enabled them to earn a lot of money from wealthy patients. Madras government allowed the civil medical practitioners to treat patients outside government facilities as an incentive during the Great War. Earlier, it was not allowed for the medical subordinates to be engaged in private practice, and the rural areas were mostly catered by local quacks. There had also been instances of the GoI not sanctioning grants to indigenous practitioners of medicine on the grounds that they were not trained in 'modern' medicine; Unani, Siddha or Ayurveda practitioners were discouraged by the government from practising even though the rural areas were in dire need of the indigenous medical expertise. ${ }^{111}$ The indigenous practitioners were not allowed any grant or funding to carry on their treatment methods in rural areas. ${ }^{112}$ Such government policies were a major deterrent for medical practitioners to engage in a hybrid (western and indigenous) form of medical practise, and this article deals with the practitioners who worked largely as agents of western medical traditions. This was also another tactic of the Madras government to encourage western educated Indians to take control of the medical marketplace and eventually establish a medical monopoly in the healthcare system. This encouraged those people trained in western medicine to move to the rural areas and continue with their work with support from the local and municipal council boards.

The Montague-Chelmsford reforms of 1919 brought the provincial government at the forefront and encouraged more local and regional participation in matters of health. The public health measures, were for most part in Madras Presidency, focussed on western medical services as part of the government initiative. The provincial government, however, was forced to become more democratic in their decision making as, by the 1920s, local people had become too invested and dependent on the western medical services in the Presidency. In 1923, the Surgeon-General of Madras declared his decision to close the outpatient departments of all district headquarter hospitals on Sundays and weekday evenings to save money and human resources. ${ }^{113}$ However, he was compelled to roll back this decision after facing strong mass protest. The introduction of district health scheme in 1923 made a positive impact on the healthcare policy in the rural parts of the presidency. This was much needed after it was reported in 1922 that the number of preventive staffs employed for public health purposes was insufficient and their activities unsatisfactory. ${ }^{114}$ Indeed, the prime focus of the government of Madras during the early 1920s was on propaganda work and less on actually treating people. The local people were engaged in public health work mostly to carry out the propaganda campaigns for the government, displaying considerable interest in such activities. ${ }^{115}$ The IMG reported that trained Indian practitioners were fighting to gain their foothold within the system through any means necessary and were not too sympathetic towards the

\footnotetext{
${ }^{108}$ IOR Mss Eur F77/189, 125-6, APAC, BL.

${ }^{109}$ Ibid.

${ }^{110}$ Op. cit. (note 100$)$.

${ }^{111}$ Medical Department, G.O. No. 409, 7 August 1920, TNSA.

${ }^{112}$ Ramasubbu, op. cit. (note 89), 7-15.

${ }^{113}$ IOR Mss Eur F77/189, no. 125-7, APAC, BL.

${ }^{114}$ Ibid., no. 136-7.

${ }^{115}$ Ibid., no. $140-1$.
} 
practitioners of indigenous medicine. ${ }^{116}$ This brought to the fore the hierarchical differences and clashes that were prevalent across the Madras Presidency among the Indian medical practitioners trained in western medicine.

\section{Local dominance over provincial control: subordinates seizing power}

This section will delve into both the connection and the discontent between the British administrators and the local leaders in the rural areas. A big challenge facing the British officials in the 1920s was to identify and segregate the 'qualified' and 'unqualified' practitioners, and this concern even found space in several issues of IMG. The medical marketplace was becoming crowded with more people joining the medical profession, but the Madras government realised that this field had largely been monopolised by the 'unqualified' practitioners, even though they were prescribing so-called scientific medicine. ${ }^{117}$ These people more often started originally as compounders with limited knowledge of the medicines and diagnosis and later assumed control in the rural areas. ${ }^{118}$ Most patients in the mofussil had no clear idea as to the courses of study undergone and the time and money spent by qualified men in obtaining their qualifications. ${ }^{19}$ They regarded equally highly anyone, irrespective of their degree, who managed to keep their dispensary crowded. ${ }^{120}$ Further, the unqualified practitioner, who was usually a compounder from the same locality, had better understanding of the area, and created a favourable impression by the use of any means available such as engaging touts and commission agents, winning over influential local people from different castes and creeds, and other controversial or disputable means that qualified medics usually stayed away from. ${ }^{121}$ Once their positions were secure and practice established, the unqualified quacks used to undertake all sorts of cases for treatment - practise medicine, surgery and midwifery alike; freely used all sorts of poisons administered intravenous injections, and managed to impress upon the common people their superiority to the qualified ones in the hospitals. Even their serious or fatal mistakes were not even reprimanded let alone punitive measures taken by the local communities. $^{122}$

In such a situation, the Subsidised Rural Medical Relief Scheme (SRMRS) was introduced in Madras in 1924. It was essentially a scheme of subsidising private practitioners who were willing to practise in villages. ${ }^{123}$ The Madras government expected to spread out the medical marketplace and expand western medical care in rural areas. ${ }^{124}$ This scheme employed about $40 \%$ of the registered practitioners as the civil assistant or sub-assistant surgeons in the medical department. ${ }^{125}$ However, as Muraleedharan has argued, the task of appointing the medical men and fixing their tenure was left to the local board presidents at their discretion. ${ }^{126}$ Records from the period reveal that qualified medics were losing their trust in the act and many did not bother to register themselves, while correspondence of medical officials

\footnotetext{
${ }^{116}$ 'The supply of rural physicians', Indian Medical Gazette 60 (1925), 223.

${ }^{117}$ 'Medical relief in rural areas', Indian Medical Gazette (1925), 193; To know more about the debate on scientific medicine, see Shinjini Das, 'Debating scientific medicine: homeopathy and allopathy in late nineteenth century medical print in Bengal', Medical History 56, 4 (2012), 463-80.

${ }^{118}$ Ibid; 'Public Health in Madras Presidency', Indian Medical Gazette 60 (1925), 192-3.

${ }^{119}$ Mofussil in Urdu, Mufassal in Persian was used originally for areas in British India which were outside the three presidency cities of Bombay, Calcutta and Madras. It usually means the areas outside the urban areas, that is, the rural ones. For more details on the divisions of Madras, see R. Suntharaligam, 'The Madras Native Association: a study of an early Indian Political Organization', The Indian Economic and Social History 4, 3 (1967), 233-63.

${ }^{120}$ Medical relief, op. cit. (note 117).

${ }^{121}$ Ibid.

${ }^{122}$ Ibid.

${ }^{123}$ Muraleedharan, 'Rural health', 323-34.

${ }^{124}$ G.O. No. 1522, Public Health, 22 October 1924, TNSA.

${ }^{125}$ Ibid.

${ }^{126}$ Muraleedharan, op. cit. (note 123).
} 
Table 4. Vacancies, number of applicants and selected candidates in Madras over 4 years.

\begin{tabular}{lccc}
\hline Year & Number of vacancies & Applicants & The number selected for admission \\
\hline $1922-23$ & 260 & 553 & 262 \\
\hline $1923-24$ & 210 & 349 & 235 \\
\hline $1924-25$ & 300 & 372 & 222 \\
\hline $1925-26$ & 250 & 238 & 143 \\
\hline
\end{tabular}

Source: Folder 65, Box 8, Series 464/464A India, RG 1.1, 1926, RF, RAC.

show how several others put serious thought into getting their names removed from the register. ${ }^{127}$ The qualified practitioners were deeply concerned with their absence of influence over the locals and were focussed on convincing the government to modify the rules of recruitment and salaries in their favour. ${ }^{128}$ Such evidence increasingly points towards how dependent the Madras government was on Indians.

Surgeon-General Hutchinson stated that the cadre for the sub-assistant surgeons in the civil medical services of Madras was reduced by approximately 150 in $1925 .{ }^{129}$ This was claimed to be a fallout of the actions taken by the local district boards in assuming the responsibility for medical service in different local hospitals, dispensaries, and so on. There were 451 sub-assistant surgeons and 30 temporary subassistant surgeons in the civil medical service of Madras in 1926. ${ }^{130}$ The decrease in the number of subassistant surgeons could be explained by the decreasing number of students in medical schools. The government was finding it difficult to understand the reason behind this as it was generally understood that the Indian students generally looked forward to securing positions within the government. ${ }^{131}$ Another reason put forward was the credit system that was introduced for studying physics and chemistry in secondary schools; thus, science subjects began to be given preference for LMP training. The third reason that contributed to a decrease in the number of students was the lack of scholarships after 1925. Only twenty scholarships were made available for women students while the rest were discontinued. ${ }^{132}$

The decreasing number of applicants (Table 4) prompted the government to take some steps to attract more subordinates. The government of Madras by this period was trying to encourage sub-assistant surgeons to settle in rural districts and had sanctioned the allotment of three subsidies for them in each taluk. ${ }^{133}$ Although, by mid-1920s, the scholarships for training the subordinates had started to dry up because of the fluctuating financial status of the GoI, as the economic depression was looming. In 1926, the Madras government declared that local boards should be permitted to appoint their medical officers in the local fund medical institutions apart from those at the headquarters of taluks. The maximum number of posts controlled by the local bodies were up to one-fourth of the total posts. ${ }^{134}$ The retrenchment committee recommended that the recruitment of the cadres directly by the provincial government should either be stopped or curtailed to give more opportunity to the practitioners aided by the local boards. ${ }^{135}$ Later, the number was increased up to $50 \%$ of the total number of sub-assistant

\footnotetext{
${ }^{127}$ Medical relief, op. cit. (note 117); Public Health Department, Report of the Director of Public Health Madras, 1928-36, IOR/V/24/3706, APAC, BL.

${ }^{128}$ Ibid.

${ }^{129}$ Interview of Major General Hutchinson SG with Madras by W.S. Carter on Madras Medical College, Folder 65, Box 8, Series 464/464A India, RG 1.1, 1926, RF, RAC.

${ }^{130}$ Ibid.

${ }^{131}$ Ibid.

${ }^{132}$ Ibid.

${ }^{133}$ Ibid.

${ }^{134}$ Local Self-govt. Department, Public Health, G.O. No. 490, 4 March 1932, APAC, BL.

${ }^{135}$ Ibid.
} 
surgeons. But this was done gradually, and after the government sub-assistant surgeons retired, their positions began to be filled up by those nominated or appointed by the local boards. ${ }^{136}$ It was decided that the government sub-assistant surgeons would be gradually withdrawn from district and taluk hospitals. The decision transformed the role played by the local fund bodies in employing medical practitioners across the presidency. The policy was intended to continue until $50 \%$ of all sub-assistant surgeons had been shifted under the local boards' command. ${ }^{137}$

The late 1920s and the beginning of 1930s witnessed a change in the attitude of the British administrators and surgeons in Madras. The subordinates were beginning to earn more respect and prestige regarding cases of surgery or any other medical skills even in the eyes of the British officials. They with their access to local politics coupled with specific skillsets began to dominate the rural and semiurban medical marketplace. The Madras government, realising the importance of local collaboration, began to publish public health booklets to encourage the locals to join and contribute to the healthcare system. ${ }^{138}$ A Tamil journal reported about a 'native' becoming health inspector of district dispensaries, which shows the locals coming forward to take up more responsibilities even in supervisory roles. ${ }^{139}$ There are several instances of Lieutenant-Colonel A.J.H. Russell remaining unavailable in Madras, either for a visit to Britain and being unable to discharge his duties as the Surgeon-General; and this allowed his subordinate Captain N.R. Ubhaya to fill up his position until 1930. ${ }^{140}$ The health propaganda work that was given significant importance by the Rockefeller Foundation was also utilised by the subordinates at the behest of the Madras government. ${ }^{141}$ In the Imperial Challenge Shield competition for the best health week celebration in the British empire, four of the seven places commended were from the Madras Presidency - Bezwada, Tuticorin, Tanjore and Chingleput. ${ }^{142}$ This demonstrated the importance of Madras and conveyed how significant a role this presidency was playing, especially in the healthcare sector. Propaganda worked in different ways in its bid to convince local people of the positive sides, when money was in shortage, appreciation worked. The Madras government was willing to fund new rural dispensaries, and it was acknowledged that the SRMRS, first introduced in 1924 was a success. ${ }^{143}$ Other such schemes to improve the condition of rural healthcare began to show signs of success such as sending LMPs as health inspectors in certain districts. ${ }^{144}$

In the absence of IMS doctors who often refused to relocate to villages, the subordinates grew indispensable to running the local dispensaries aimed at treating local people. These shifts and changes that occurred in the Madras Presidency gave rise to a new social category. This category brought together people from diverse caste, religious, linguistic and class backgrounds to create a distinctive bureaucratic community that one can refer to as the ascendant section or the social ascendants in Madras society. These people were not interested in moving outside their locality; they were happy consolidating power and prestige in the area and did not go into direct confrontation with the British officials. But unofficially, the Madras government had to give them enough importance and attention when passing any resolution or make any legislative changes in the districts, taluks and villages. The subordinates, while functioning within the folds of the government to propagate the superiority of western medicine and collaborating with the seat of power in maintaining the established status quo, also made use of local political power structure to ensure that their exclusive influence remained unchallenged. Such a nature of local dominance and control resonates strongly with the concept of thick and thin hegemony by James Scott, as the social ascendants were capable enough to work together in turning the table and establishing a

\footnotetext{
${ }^{136}$ Ibid.

${ }^{137}$ Ibid.

${ }^{138}$ An Appeal to the Educated Men of the Country (Public Health Department Madras: Superintendent, Government Press, 1929).

${ }^{139}$ Kumaran, 'Cukātāra vāram' (Health Inspector), 6, 53 (1929).

${ }^{140}$ Public Health Department, op. cit. (note 127).

${ }^{141}$ Ibid.

${ }^{142}$ Ibid; 'Taluk Hospitals and Dispensaries', The Hindu September 19 (1930), 9.

${ }^{143}$ Annual Report of the civil hospitals and dispensaries, 1931, BL.

${ }^{144}$ Ibid.
} 
hegemony of their own. ${ }^{145}$ Scott's theory was based on examining the relatively powerless groups and what sort of resistance they were offering to organised political activities. His purpose was to propose a new way of understanding political conduct between the dominant and the subordinate groups. In this way, Scott opened up a new perspective to understand how the subordinate group or groups and the forces of power tacitly conspire. His theory points out how thin hegemony works in such cases, as the subordinates endorse how the dominant group wants something to appear, which opens up a very interesting discussion about who holds the real power in this context. Madras Presidency, through their medical care structure and services, reflected this theory as will be explained here. Contrary to the existing literature, it shows a hegemonic influence of the local groups, and how the provincial government was constantly trying to break this 'thin hegemony' to establish their governance. These socially ascendant groups were significant in moulding the medical scene in the rural regions and were quick to establish their influence over weaker sections of Indians and, later, over the district or city administration.

The year 1930 marked a significant change to the attitude of the British administrators in Madras, and this had a positive impact on the position and influence of the subordinates working in the presidency. Various district officer ranks (Anantapur, Vizagapatam), and a few in minor hospitals in the city of Madras were made available for the subordinates with effect from 1 July $1930 .{ }^{146}$ Such a development elevated the social prestige of the SMS recruits in the eyes of the general public. There were journals published in local languages urging people to take more interest in public and community healthcare. ${ }^{147}$ However, the economic depression had a huge impact on the SRMRS scheme, and there was a slowdown in the number of medics subsidised by the local government by $1932 .{ }^{148}$ The medical subordinates who were already posted in the rural areas took up the mantle to continue the work that would give them control over the population. In several festivals in the districts of Madura, West Godavari, Nellore, South Kanara and Tanjore, there were reports that the recommendations of the public health department were not carried out properly. ${ }^{149}$ There were certain pieces of evidence that pointed towards the local bodies taking advantage of a few provisions of the Local Boards Act and of the Districts Municipalities Act in religious matters. ${ }^{150}$ The region showed considerable interest in establishing western medical care and the local inhabitants were constantly trying to reach an advantageous position in such a structure. There was sustained interest among the state and IMS officers in charge of the presidency to expand the western healthcare as they were trying to expand the influence and spread of health monopoly. J.R.D. Webb, the Director of Public Health in 1932, declared,

... glories of good Public Health will not be achieved by singing "Oh! How beautiful" and sitting in the shade. We must take "our-coats-off" and try and apply the teachings and preachings of our Professors and Research workers by a practical application in that immense field for Public Health endeavour, the "Rural India." 151

This demonstrates the patronising attitude of the British administrators towards the people in the rural regions. However, rural healthcare scheme was close-knit, and as explained earlier in the article was being controlled by the local boards in their individual areas and districts. With their distinct medical and political structure, Madras Presidency witnessed the rise of local pockets of power, explained earlier as

\footnotetext{
${ }^{145}$ James C. Scott, Domination and the Art of Resistance: Hidden Transcripts (New Haven; London: Yale University Press, 1990).

${ }^{146}$ Ibid.

${ }^{147}$ Venkatesa Sharma, 'Illānmmai, allatu, kuṭumpa cukātāra paripālañam' (Lack of health perception in families) (Gopalakrishnan, 1931).

${ }^{148}$ V.R. Muraleedharan, 'Professionalising Medical Practice in Colonial South-India', Economic and Political Weekly 27, 4 (1992), 27-30, 35-7.

${ }^{149}$ V/24/3706, Public Health, 1929-35, APAC, BL.

${ }^{150}$ Ibid.

${ }^{151}$ V/24/3706, Public Health, 1932, APAC, BL.
} 
social ascendants where a group of local people in the rural areas were collaborating and competing with people from other districts because of their differences in language, religion or social standing.

In the mid-1930s, the previously watertight division between the urban and the rural was becoming blurred with the expansion of city limits and also medical care - in turn expanding the medical marketplace. Local authorities began to be classified into urban local authorities and 'other' authorities. ${ }^{152}$ The urban local authorities consisted of the corporation of Madras, municipal councils and panchayats specifically notified by the government. ${ }^{153}$ Overall, the provincial government was held accountable for all the local activities, but in reality, the local authorities were allowed to function undisturbed in their way of dealing with health matters. ${ }^{154}$ However, while this method worked impeccably in favour of the Indians trying to expand their control locally, it did not provide much opportunity for expansion of medical research or extension of research institutes in the rural areas. The public health administration in the 1930s had complete details of the various medical schools, colleges and their infrastructural work, but had strikingly summarised only the details of actual medical research. The medical journals and gazettes of the time largely overlooked or discouraged any medical research by the Indians.

The GoI Act 1935 recognised the power these local boards wielded over the provincial administration and they tried to give some control back to the hierarchically superior officers. However, the local boards could maintain their control over these health officers, although they were given the right to appeal against the local boards to higher authorities. ${ }^{155}$ The contested role remained the same, if not worsened by the mid-1930s. A minister commented about a town where he knew, 'the sanitary inspectors were asked to collect taxes instead of performing sanitary work. There were municipal councils which had defied the officers of the health department'. ${ }^{156}$ Such incidents increasingly highlight the influence of the ascendant sections in the Madras Presidency and how they not only retained their power locally but compelled the government health officials to comply with their demands and actions.

\section{Conclusion}

This article is based on the premise that the Madras Presidency provided a favourable ground for local residents from different social backgrounds to become an integral part of the medical marketplace. Rather than focussing merely on the so-called elites, this work concentrates on the subordinate sections the intermediaries who took advantage of the fissures in the government structure and tightened their control over local politics and administration. This article considers the role of medical subordinates such as the compounders and dressers in the expansion of western medical care in the presidency. Because of the uneven nature of archival records, especially in a variety of Indian archives, preserving only fragmented traces of subordinate contributions, their role finds almost no mention in the existing literature. ${ }^{157}$ A careful assessment of the archival sources available in different countries presents a highly diverse and heterogeneous scenario. Madras Presidency, with its mix of Tamil, Telugu, Canarese, Malayali and Oriya speakers, renders it impossible to club the local residents under one umbrella community, as has frequently been done in case of Bengal Presidency and Bengalis. ${ }^{158}$ The medical subordinates or health workers cannot be considered a homogeneous entity, as different socio-political constructs shaped and altered their nature during the period under review. Their social roles, educational

\footnotetext{
${ }^{152}$ C.V. Naidu, The Public Health in Madras Province (Tiruvallur: Rajeswari \& Co., 1939), 18-19.

${ }^{153}$ Ibid.

${ }^{154}$ Ibid.

${ }^{155}$ P.R. Aiyar, The Madras Public Health Act (Madras: The Madras Law Journal Officer, Mylapore, 1939), 5-7.

${ }^{156}$ Ibid.

${ }^{157}$ Khalid, Subordinate negotiations, op. cit. (note 4); Khalid and Johnson, ed. Public Health in the British Empire, op. cit. (note 4).

${ }^{158}$ Projit Bihari Mukharji, Nationalizing the Body: The Medical Market, Print and Healing in Colonial Bengal (London: Anthem, 2009).
} 
motivations and professional designations changed during the late nineteenth and early twentieth centuries, and in a way, they can be compared to the Bengali daktars as Projit Mukharji has argued in the context of Bengal. ${ }^{159}$ However, the subordinates in colonial Madras were even more heterogeneous, considering that they hailed from diverse linguistic backgrounds, and the heterogeneity was reflected in the social and professional lives of the subordinates.

Borrowing from James C. Scott's theory on thick and thin hegemony, this article argues that as the medical marketplace began to expand and spread from urban to rural and remote areas, the roles of the subordinates became more critical. ${ }^{160}$ In recording the dynamic role of the SMS and recognising them as social ascendants, this article adds a new dimension to the study of healthcare structures during the colonial period. Breaking out of the binary of the coloniser and the colonised, it emphasises the collaboration and competition not only between the British and Indians, but also various groups of Indians to establish the hegemony of western medicine across the presidency. As the article has pointed out, the subordinates in Madras were deeply involved in the colonial medical system, but the involvement was on various levels, and they contributed in very distinct manners. Only by accessing the subordinate perspectives, a more nuanced understanding of colonial healthcare can be attained. The article has also shown the need to re-evaluate assumptions about the medical administration of the empire, and how local, regional interests underpinned those administrative processes. Finally, this article points out the cultural, social and linguistic factors that worked in collusion to influence the medical structure in the presidency.

This article challenges the literature on western healthcare at different levels and emphasised that the lack of regional and local perspectives has hampered our understanding of the aspects of expansion and establishment of medical care in colonial India. The focussed study of healthcare in colonial Madras has provided a new framework to understand the history of this province's colonial encounter that has so far been overshadowed by discourses on other presidencies and generalisations. It has also accentuated the centrality of the archive - in particular, the regional and vernacular sources - to demonstrate that new materials enable the formation of unique perspectives offering insights often overlooked in a bid to pursue global and wider studies.

Acknowledgement. The research underpinning this article was supported by the Wellcome Trust grant 108589/Z/15/Z. I would like to express my gratitude to the funder, the anonymous referees for their extremely helpful comments and the editor of Medical History.

\footnotetext{
${ }^{159}$ Ibid.

${ }^{160}$ Scott, op. cit. (note 145).
}

Cite this article: Chakraborty A (2021). Negotiating medical services in the Madras Presidency: the subordinate perspectives (1882-1935). Medical History 65: 247-266, https://doi.org/10.1017/mdh.2021.15 